\title{
Immunohistowax processing, a new fixation and embedding method for light microscopy, which preserves antigen immunoreactivity and morphological structures: visualisation of dendritic cells in peripheral organs
}

Bernard Pajak, Thibaut De Smedt, Véronique Moulin, Carl De Trez, Roberto Maldonado-López, Georgette Vansanten, Emmanuel Briend, Jacques Urbain, Oberdan Leo, Muriel Moser

The Département de Biologie Moléculaire, Université Libre de Bruxelles, B-1640 Rhode-Saint-Genèse, Belgium

B Pajak

V Moulin

C De Trez

R Maldonado-López

G Vansanten

J Urbain

O Leo

M Moser

Immunex

Corporation, Seattle,

Washington 98101, USA

T De Smedt

Cantab

Pharmaceuticals

Research LDT,

Cambridge CB4 OWG,

UK

E Briend

Correspondence to: Dr Pajak, Laboratoire de

Physiologie Animale, Institut de Biologie et Médecine

Moléculaire, Université Libre de Bruxelles, Rue des Profs

Jeener et Brachet, 12, B-6041

Gosselies, Belgium

email:

bpajak@dbm.ulb.ac.be

Accepted for publication 20 January 2000

\begin{abstract}
Aims-To describe a new fixation and embedding method for tissue samples, immunohistowax processing, which preserves both morphology and antigen immunoreactivity, and to use this technique to investigate the role of dendritic cells in the immune response in peripheral tissues.

Methods-This technique was used to stain a population of specialised antigen presenting cells (dendritic cells) that have the unique capacity to sensitise naive $T$ cells, and therefore to induce primary immune responses. The numbers of dendritic cells in peripheral organs of mice either untreated or injected with live Escherichia coli were compared.

Results-Numbers of dendritic cells were greatly decreased in heart, kidney, and intestine after the inoculation of bacteria. The numbers of dendritic cells in the lung did not seem to be affected by the injection of $E$ coli. However, staining of lung sections revealed that some monocyte like cells acquired morphological and phenotypic features of dendritic cells, and migrated into blood vessels.

Conclusions-These observations suggest that the injection of bacteria induces the activation of dendritic cells in peripheral organs, where they play the role of sentinels, and/or their movement into lymphoid organs, where $T$ cell priming is likely to occur.

(F Clin Pathol 2000;53:518-524)
\end{abstract}

Keywords: dendritic cell; Escherichia coli; immunohistochemistry

The immune response is the result of multiple interactions between discrete cell populations of the immune system. Specialised cells (antigen presenting cells (APCs)) present the antigen, in the form of peptides in the groove of major histocompatibility complex (MHC) molecules, to helper T cells, which in turn activate the differentiation of effector cells, such as B cells or cytotoxic effector cells. APCs are widely distributed in the body, in lymphoid and non-lymphoid organs, ${ }^{1}$ whereas $\mathrm{T}$ cells recirculate through the lymphoid organs, where they are located in discrete sites. There is evidence that $\mathrm{T}$ cell priming occurs in the $\mathrm{T}$ cell zones of lymphoid organs. ${ }^{23}$ Therefore, the first step of the immune response is likely to involve the migration of APCs and their redistribution into $\mathrm{T}$ cell areas.

The population of APCs is heterogeneous and includes dendritic cells, B cells, and macrophages. Among these cells, dendritic cells appear to have the unique capacity to sensitise naive T cells and are the APCs of the primary immune response.

The aim of our study was to analyse the movement of dendritic cells in peripheral solid organs of mice injected with Gram negative bacteria. To achieve this goal, a new immunohistochemistry processing (immunohistowax processing) method, based on a proprietary fixation and embedding medium, was developed and was shown to preserve both morphology and antigen immunoreactivity. In this processing, protein denaturation in the sample is minimised by the combined use of an aldehyde free zinc salt solution and a new embedding wax (Immunohistowax), which is liquid at low temperature $\left(37^{\circ} \mathrm{C}\right)$. This approach allowed us to identify dendritic cells by morphological as well as phenotypic criteria. Our data show that most dendritic cells disappear from kidney, heart, and intestine after the injection of bacteria, whereas some lung dendritic cells become activated under the same conditions.

Materials and methods

ANIMALS

Female Balb/c and C57BL/6 mice were purchased from IFFA-CREDO (Brussels, Belgium) and maintained in our pathogen free facility.

\section{ESCHERICHIA COLI INOCULATION}

The K504 E coli strain was kindly provided by Dr E Van Driessche (Laboratorium voor Chemie der Proteinen, Vrije Universiteit Brussel, Belgium). Bacteria were grown in LB medium overnight at $37^{\circ} \mathrm{C}$. Bacteria were pelleted by centrifugation at $3000 \times g$ for 10 
Table 1 Effect of zinc fixation on antigen preservation

\begin{tabular}{|c|c|c|c|c|c|c|c|c|}
\hline \multirow[b]{2}{*}{ Fixation } & \multirow[b]{2}{*}{ Dehydration } & \multicolumn{7}{|c|}{ Staining score } \\
\hline & & MHC II & $C D 11 c$ & $B 220$ & $M a c-1$ & $C D 3$ & $C D 4$ & $C D 8$ \\
\hline & Acetone & +++ & +++ & +++ & +++ & - & - & - \\
\hline $\begin{array}{l}\text { Zinc fixative } \\
\text { (3 days) } \\
\text { Zinc fixative }\end{array}$ & Acetone & +++ & +++ & +++ & +++ & ++ & ++ & ++ \\
\hline (3 days) & Ethanol & +++ & +++ & +++ & +++ & ++ & ++ & ++ \\
\hline
\end{tabular}

Acetone: one bath of $100 \%$ acetone for six hours.

Ethanol: graded series of $30 \%, 50 \%, 70 \%, 90 \%$, and $100 \%$ of ethanol, 30 minutes in each bath - , Negative; + , weakly positive; ++, positive; +++, strongly positive.

MHC, major histocompatibility complex.

minutes, washed twice in sterile phosphate buffered saline (PBS) and resuspended at $5 \times 10^{8}$ bacteria $/ \mathrm{ml}$ in PBS. A standard of absorbencies based on known colony forming units (CFU) was used to calculate the inoculum concentration. Mice received an intravenous injection of $200 \mu \mathrm{l}$ of $E$ coli suspension. An $E$ coli dose of $10^{8} \mathrm{CFU}$ was used in all experiments.

IMMUNOHISTOWAX PROCESSING

The tissue sample was fixed in a formaldehyde free zinc fixative (Immunohistofix; Intertiles, Brussels, Belgium) for three days at $4^{\circ} \mathrm{C}$. Sample thickness did not exceed $5 \mathrm{~mm}$ to allow optimal infiltration of fixative and dehydrating agents. Dehydration was performed according to two different protocols: the samples were either dehydrated in a graded series of ethanol baths: $30 \%, 50 \%, 70 \%, 90 \%$, and $100 \%$ for 30 minutes each at room temperature, or samples were dehydrated in $100 \%$ acetone for six hours. The first protocol seems to preserve tissue morphology more effectively, whereas the second possibly preserved some antigens more efficiently. Infiltration was performed at $37^{\circ} \mathrm{C}$ by means of three baths of Immunohistowax for 20 minutes each. Tissue specimens were then embedded in Immunohistowax and mounted on wooden blocks. Blocks were stored at $4^{\circ} \mathrm{C}$ for at least one night before sectioning, and could be kept for up to six months at room temperature. Blocks can become difficult to cut at temperatures above $22^{\circ} \mathrm{C}$, and were therefore kept at $4^{\circ} \mathrm{C}$ and cut promptly. Sections of 3-5 $\mu \mathrm{m}$ were performed with a sliding microtome and individual sections were transferred directly using thin grids on a drop of water on gelatin precoated slides. Floating on a water bath is unsuitable because of the slight hydrophilicity of the wax. Slides were air dried at room temperature and stored at room temperature for up to several months.

IMMUNOSTAINING

Immunohistowax processed sections were dewaxed in acetone for one to five minutes and

Table 2 Antigens successfully detected on Immunohistowax processed mouse tissue sections

\begin{tabular}{|c|c|c|c|c|}
\hline Antigens & Clones & Specificity & Dilution & Sources \\
\hline $\mathrm{CD} 2$ & $12-15$ & Cell adhesion molecule & $10-20 \mu \mathrm{g} / \mathrm{ml}$ & $\begin{array}{l}\text { Southern Biotechnology } \\
\text { Associates, Inc }\end{array}$ \\
\hline CD3 & 7D6 & $\mathrm{T}$ cells & $20-30 \mu \mathrm{g} / \mathrm{ml}$ & Coulie and colleagues ${ }^{14}$ \\
\hline $\mathrm{CD} 4$ & RM4-5 & $\mathrm{T}$ helper cells & $20 \mu \mathrm{g} / \mathrm{ml}$ & Pharmingen \\
\hline CD8 & $53-6.7$ & $\mathrm{~T}$ cells & $20 \mu \mathrm{g} / \mathrm{ml}$ & Pharmingen \\
\hline CD90/Thy 1.2 & $53-2.1$ & $\mathrm{~T}$ cells & $10-20 \mu \mathrm{g} / \mathrm{ml}$ & Pharmingen \\
\hline $\mathrm{TCR} \alpha \beta$ & H57-597 & $\mathrm{T}$ cells (TCR) & $20-30 \mu \mathrm{g} / \mathrm{ml}$ & Pharmingen \\
\hline $\mathrm{TCR} \gamma \delta$ & $13 \mathrm{D} 5$ & $\mathrm{~T}$ cells (TCR) & $20-30 \mu \mathrm{g} / \mathrm{ml}$ & Peterman and colleagues ${ }^{15}$ \\
\hline TCR V $\beta 8$ & $\mathrm{~F} 23.2$ & $\mathrm{~T}$ cells (TCR) & $20 \mu \mathrm{g} / \mathrm{ml}$ & ATCC \\
\hline TCR V $\beta 6$ & 44.22 .1 & $\mathrm{~T}$ cells (TCR) & $20 \mu \mathrm{g} / \mathrm{ml}$ & Payne and colleagues ${ }^{16}$ \\
\hline B220/CD $45 R$ & RA3-6B2 & B cells & $5-10 \mu \mathrm{g} / \mathrm{ml}$ & Pharmingen \\
\hline $\operatorname{IgD}$ & LoMD6 & B cells & $5-10 \mu \mathrm{g} / \mathrm{ml}$ & Lefebvre and colleagues ${ }^{17}$ \\
\hline $\operatorname{IgM}$ & LoMM9 & B cells & $5-10 \mu \mathrm{g} / \mathrm{ml}$ & Lefebvre and colleagues ${ }^{17}$ \\
\hline MHC-II & 14.4 .4 & B cells, DC, M $\phi$ & $5-10 \mu \mathrm{g} / \mathrm{ml}$ & ATCC \\
\hline CD11c & N418 & Mainly DC & $5-10 \mu \mathrm{g} / \mathrm{ml}$ & Metlay and colleagues ${ }^{18}$ \\
\hline CD11c & HL3 & Mainly DC & $5-10 \mu \mathrm{g} / \mathrm{ml}$ & Pharmingen \\
\hline CD11b/Mac-1 & $\mathrm{M} 1 / 70$ & $\mathrm{M} \Phi$ & $5-10 \mu \mathrm{g} / \mathrm{ml}$ & Pharmingen \\
\hline NK & $5 \mathrm{E} 6$ & NK cells & $10-20 \mu \mathrm{g} / \mathrm{ml}$ & Pharmingen \\
\hline Pan-NK & DX5 & NK cells & $10-20 \mu \mathrm{g} / \mathrm{ml}$ & Pharmingen \\
\hline Ly-6G/GR1 & RB6-8C5 & Granulocytes & $10-20 \mu \mathrm{g} / \mathrm{ml}$ & Pharmingen \\
\hline PMN antigen & $7 / 4$ & Neutrophils & $10-20 \mu \mathrm{g} / \mathrm{ml}$ & Caltag \\
\hline $\mathrm{CD} 40$ & $3 / 23$ & B cells, DC, MФ & $10-20 \mu \mathrm{g} / \mathrm{ml}$ & Hasbold and colleagues $^{19}$ \\
\hline $\begin{array}{l}\text { Intracytoplasmic } \\
\text { granules }\end{array}$ & $2 \mathrm{~A} 1$ & Mature DC & $5-10 \mu \mathrm{g} / \mathrm{ml}$ & Inaba and colleagues ${ }^{20}$ \\
\hline $\begin{array}{l}\text { Intracytoplasmic } \\
\text { granules }\end{array}$ & M342 & Mature DC & $\begin{array}{l}\text { Undiluted } \\
\text { supernatant }\end{array}$ & Agger and colleagues ${ }^{21}$ \\
\hline DEC-205 & NLDC-145 & Mature DC & $20-30 \mu \mathrm{g} / \mathrm{ml}$ & Kraal and colleagues $^{22}$ \\
\hline CD35 & $8 \mathrm{C} 12$ & CR1 (Follicular DC) & $5-10 \mu \mathrm{g} / \mathrm{ml}$ & Pharmingen \\
\hline $\mathrm{CD} 86 / \mathrm{B} 7.2$ & GL1 & Activated B cells, DC, M $\phi$ & $10-20 \mu \mathrm{g} / \mathrm{ml}$ & Hathcock and colleagues ${ }^{23}$ \\
\hline $\mathrm{CD} 25$ & 7D4 & Activated T cells, B cells, DC & $10-20 \mu \mathrm{g} / \mathrm{ml}$ & Pharmingen \\
\hline Ly-77 & GL7 & Activated $\mathrm{T}$ cells, B cells & $10-20 \mu \mathrm{g} / \mathrm{ml}$ & Pharmingen \\
\hline CD44 & $1 \mathrm{M} 7$ & Activated $\mathrm{T}$ cells & $10-20 \mu \mathrm{g} / \mathrm{ml}$ & Pharmingen \\
\hline CD69 & $\mathrm{H} 1.2 \mathrm{~F} 3$ & Activated $\mathrm{T}$ cells & $10-20 \mu \mathrm{g} / \mathrm{ml}$ & Pharmingen \\
\hline Phosphotyrosin & $4 \mathrm{G} 10$ & Activated cells & $20-30 \mu \mathrm{g} / \mathrm{ml}$ & $\begin{array}{l}\text { Upstate Biotechnology } \\
\text { Incorporation }\end{array}$ \\
\hline OX 40 & $\mathrm{mOX} 40 \mathrm{~L}-\mathrm{hIgG} 1^{\star}$ & Activated T cells & $20-30 \mu \mathrm{g} / \mathrm{ml}$ & $\begin{array}{l}\text { Cantab Pharmaceutical } \\
\text { Research Ltd }\end{array}$ \\
\hline VCAM-1 & $\mathrm{M} / \mathrm{K}-2$ & Adhesion molecule & $10-20 \mu \mathrm{g} / \mathrm{ml}$ & R\&D Systems \\
\hline Anti-Ars Ig & Ars-BSA $^{\circ}$ & Ars specific B cells & $20 \mu \mathrm{g} / \mathrm{ml}$ & \\
\hline IL-2 & S4B6 & Cytokine & $20-30 \mu \mathrm{g} / \mathrm{ml}$ & Pharmingen \\
\hline IL-4 & $11 \mathrm{~B} 11$ & Cytokine & $20-30 \mu \mathrm{g} / \mathrm{ml}$ & Pharmingen \\
\hline INF- $\gamma$ & Db1 & Cytokine & $20-30 \mu \mathrm{g} / \mathrm{ml}$ & Paineau and colleagues ${ }^{24}$ \\
\hline IL-10 & JESS-2A5 & Cytokine & $20-30 \mu \mathrm{g} / \mathrm{ml}$ & Pharmingen \\
\hline
\end{tabular}

${ }^{\star}$ Fusion protein; ${ }^{\circ}$ synthesised hapten carrier protein.

Ars, arsenate; BSA, bovine serum albumin; DC, dendritic cell; h, human; IFN- $\gamma$, interferon $\gamma$; Ig, immunoglobulin; IL, interleukin; L, ligand; MHC, major histocompatibility complex; MФ, macrophage; NK, natural killer; PMN, polymorphonuclear cell; TCR, T cell receptor; VCAM, vascular cell adhesion molecule. 

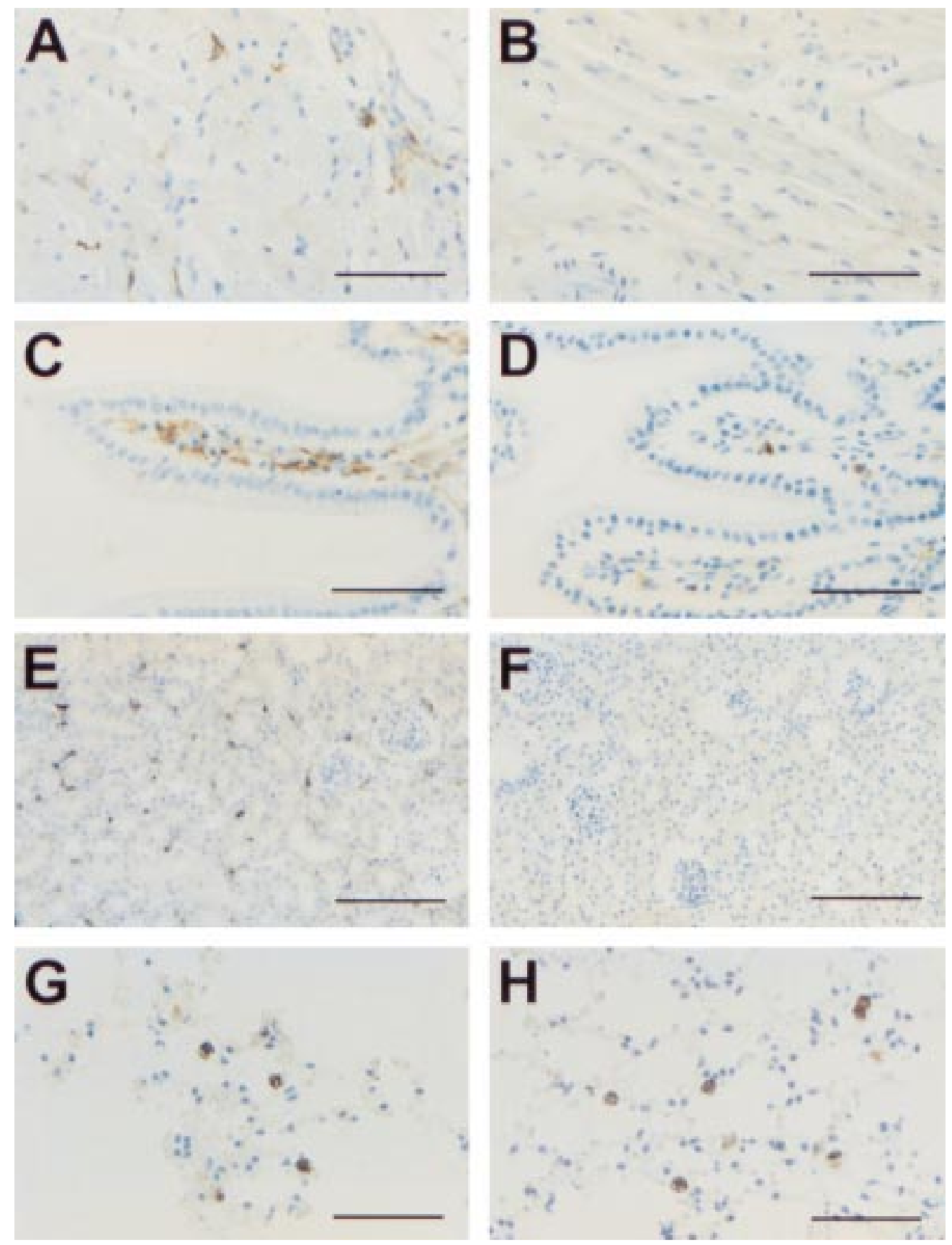

Figure 1 Immunostaining of major histocompatibility complex (MHC) class II positive or CD11c positive cells in organs of mice injected or not injected with bacteria. Heart $(A$ and $B$ ), intestine $(C$ and $D)$, kidney ( $E$ and $F$ ), and lung ( $G$ and

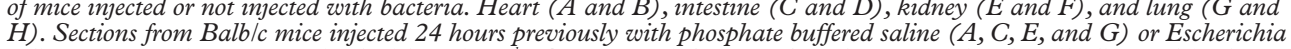
coli $(B, D, F$, and $H)$ were stained with anti-I- $E^{d}(A-F)$ or anti-CD11c $(G$ and $H)$ monoclonal antibodies, and further counterstained with haemalun. Scale bar, $50 \mu \mathrm{m}$ ( $A, B, C, D, G$, and $H), 100 \mu \mathrm{m}$ ( $E$ and $F$ ).

transferred to PBS. Immunohistochemical staining was performed as follows.

Inhibition of endogenous peroxidases

If peroxidase was used for visualisation, the slides were first treated with $3 \% \mathrm{H}_{2} \mathrm{O}_{2}$ in PBS for 30 to 60 minutes to block endogenous peroxidase; the use of methanol was avoided because it might be detrimental for certain antigens, such as $\mathrm{T}$ cell markers.

Saturation step

We commonly use the blocking reagent (catalogue number, 1096176) from Boehringer (Brussels, Belgium; 1\% in PBS (PBS-BR)) to saturate non-specific reaction sites because it gives a lower background than bovine serum albumin, horse serum, or goat serum. Sections were incubated in PBS-BR at room temperature for 30 minutes.

\section{Single staining}

Sections were washed in PBS and incubated with antibodies $(5-25 \mu \mathrm{g} / \mathrm{ml})$ for one to three hours at room temperature or overnight at $4^{\circ} \mathrm{C}$ in PBS-BR. Primary monoclonal antibodies gave better results when coupled to biotin or fluorescein isothiocyanate (FITC). Biotinylated antibodies were visualised with $\mathrm{ABC}$ kits from Vector Laboratories (Burlingame, 


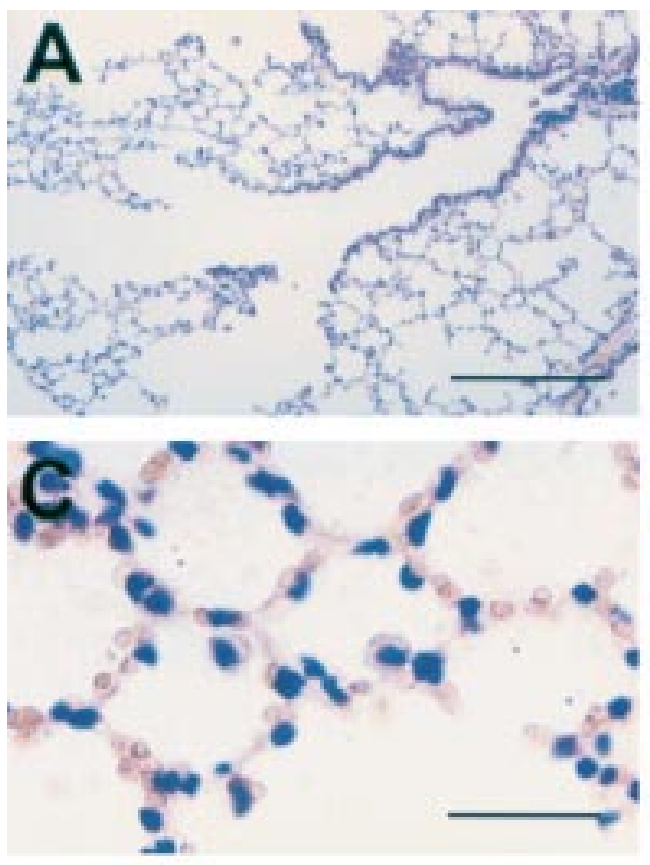

Figure 2 Histopathology of the lung after Escherichia coli injection. Lungs from Balb/c mice injected with phosphate buffered saline ( $A$ and $C$ ) or $E$ coli $(B, D$, and $E)$ one hour previously were fixed, dehydrated, and embedded according to the Immunohistowax processing protocol and stained with haemalun-eosin. Note the infiltration of neutrophils in alveoli (D) and in arterioles (E). Scale bars, $250 \mu \mathrm{m}$ ( $A$ and $B) ; 25 \mu m(C-E)$.

California, USA; $1 / 100$ in PBS-BR) for 30 minutes at room temperature. Peroxidase was revealed using either diaminobenzidine substrates with or without metal enhancer (Sigma, Bornem, Belgium), TMB, Vector SG Substrate Kit, Vector VIP Substrate Kit (Vector), or AEC (Sigma). Substrate kits from Vector Laboratories for alkaline phosphatase were used according to the manufacturer's recommendations. FITC conjugated antibodies were visualised by incubation for 30 minutes with anti-FITC alkaline phosphatase or peroxidase Fab fragment (Boehringer), diluted at 1/500 in PBS-BR.

\section{Counterstaining}

Single immunostained sections were counterstained with haematoxylin or methyl green depending on the substrate colour.

When double or triple staining was performed with biotinylated antibodies, excess biotin from the first antibody was blocked with the Vector blocking kit. In the case of multiple peroxidase stainings, enzymatic activity linked to the first antibody was neutralised by incubating sections in $\mathrm{H}_{2} \mathrm{O}_{2}(3 \%$ in $\mathrm{PBS})$ for 20-30 minutes.

\section{Mounting}

Slides were mounted in Aquatex (Merck, Overijse, Belgium) or Polymount (Polysciences, Warrington, USA) depending on the solubility of substrates.
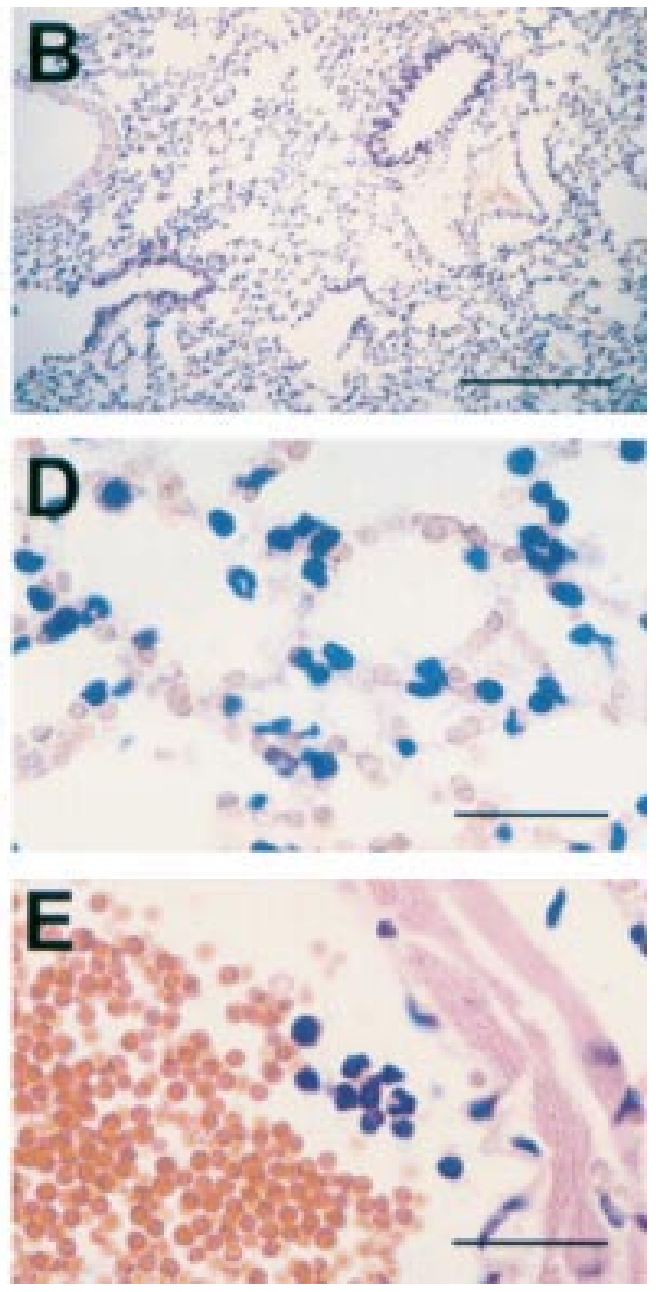

\section{Results}

IMMUNOHISTOWAX PROCESSING

Morphological observations require thin tissue sections, which are best obtained after the infiltration and embedding of specimens with wax or plastic. However, because waxes are poorly soluble in water, their use requires pretreatment with fixatives and dehydrating solvents, which is known to affect protein structure. In addition, fixation and/or embedding can also affect the immunodetection of many cellular markers as a result of protein denaturation caused by chemical and/or thermal injury. ${ }^{4-6}$ Although we have developed a novel wax that is liquid at near physiological temperature $\left(37^{\circ} \mathrm{C}\right)$, its poor solubility in water required tissue dehydration before embedding. Dehydration was performed with acetone or ethanol, which were fully miscible in the liquid wax. Unfortunately, and as expected from previous reports, ${ }^{7}$ the dehydration step affected the staining of many antigens. The data in table 1 show that dehydration prevented the staining of CD3, CD4, and CD8 antigens. By contrast, other antigens, such as MHC class II, CD11c, B220, and Mac-1 were not altered by dehydration with one bath of $100 \%$ acetone for six hours.

Because exposure to organic solvents before embedding could not be avoided, we attempted to protect antigenic structures from chemical denaturation by increasing protein stability 

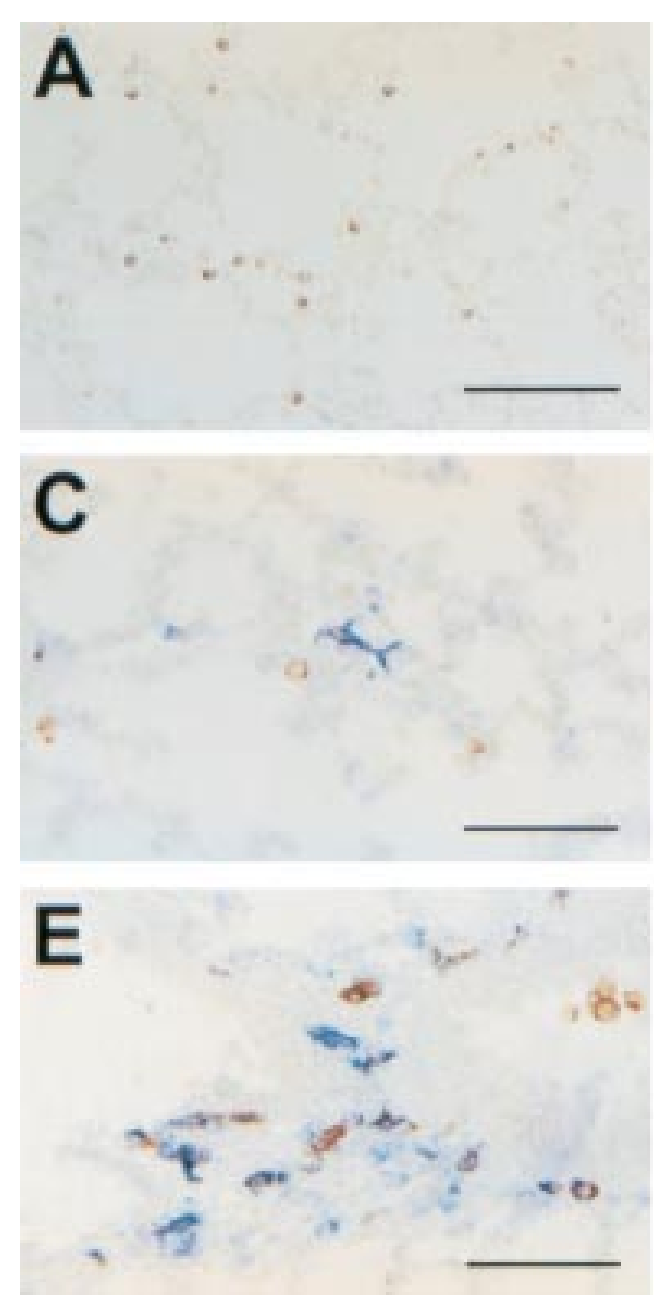

before fixation. Engineered metal chelation in proteins has been used successfully to stabilise proteins against denaturation. ${ }^{89}$ We choose $\mathrm{Zn}^{2+}$ as a metal ion, based on its known ability to interact with at least four amino acids (primarily histidine, and to a lesser extent, aspartic acid, glutamic acid, and cysteine) through binding to nitrogen, oxygen, and sulphur atoms. ${ }^{10} 11$ Its thermodynamic properties have been shown to promote favourable entropic effects, which enhance the stability of secondary protein structure. ${ }^{12}$ Ligand motifs that can be used for metal binding are His-XXX-His for an $\alpha$-helix, His-X-His for a $\beta$-strand, and His-XXHis for a reverse type II $\beta$-strand. ${ }^{13}$ In some cases, one or two histidine(s) might be replaced by aspartate or cysteine. We analysed mouse protein sequences and found that at least one motif was present in all sequences investigated, the mean value being 3.5 motifs/sequence. Although structural data are not available for most antigenic proteins, we assumed that a sufficient number of these motifs was indeed able to bind a metal ion.

Tissue specimens were pretreated with a zinc fixative (Immunohistofix), dehydrated, and embedded in Immunohistowax. We compared the staining of several antigens on tissue samples, pretreated or not with zinc fixative. The data in table 1 show that the staining of CD3, CD4, and CD8 antigens was preserved by pretreatment with the zinc fixative. We fur-
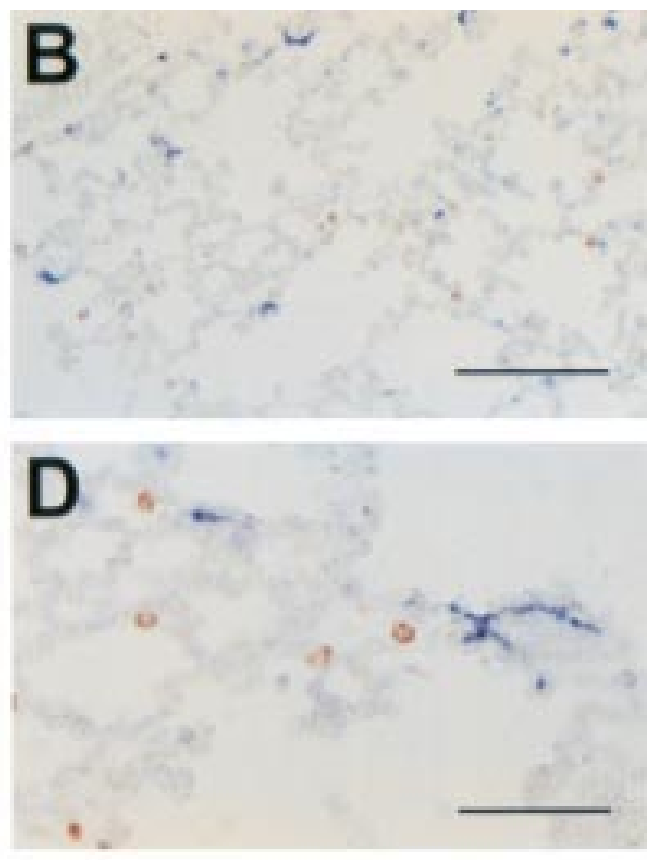

Figure 3 Phenotype and morphology of lung dendritic cells after the inoculation of bacteria. Immunohistowax processed lung sections from mice injected with phosphate buffered saline $(A)$ or live Escherichia coli $(B-E)$ were double stained with anti-CD11c in red and anti-I- $E^{d}$ in blue. Note the CD11c positive, major histocompatibility complex class II positive cells in purple $(B-E)$. Scale bars, $100 \mu \mathrm{m}(A$ and $B) ; 50 \mu m(C-E)$.

ther tested several monoclonal or polyclonal antibodies, fusion proteins, lectins, and enzymes for the staining of membrane or intracellular proteins, carbohydrate residues, surface receptors, and apoptotic cells. The results in table 2 show that a large number of molecules expressed by T or B cells, NK cells, macrophages, and dendritic cells could be detected on Immunohistowax processed sections. In particular, determinants expressed upon cell activation were stained using monoclonal antibodies (specific for CD25, CD44, CD69, CD86, Ly-77, or DEC-205) or a fusion protein (OX40 ligand-human IgG1). B cells specific for the hapten arsonate were visualised on spleen sections using the hapten coupled to bovine serum albumin (BSA), whereas T cells were stained with a monoclonal antibody specific for their antigenic receptor. Interleukin 2 (IL-2), IL-4, interferon $\gamma$ (IFN- $\gamma$ ), and IL-10 were detected in the cytoplasm of activated $\mathrm{T}$ cells in situ, using double staining with antibodies to $\mathrm{T}$ cells and to lymphokines. Using this processing method, we previously identified apoptotic cells in tissues by double staining with antibodies to cell surface markers and the TUNEL (TdT mediated dUTP nick end labelling) reaction. ${ }^{25}$ It should be noted that, among all presently tested antibodies, only two did not work with this technique: 2C11 (hamster antimouse CD3) and GK1.5 (rat antimouse CD4). 
INJECTION OF GRAM NEGATIVE BACTERIA REDUCES THE NUMBER OF DENDRITIC CELLS IN KIDNEY, HEART, AND INTESTINE

Dendritic cells are a trace population in most organs, usually display dendrites, and express selected surface markers, such as MHC class II molecules and/or CD11c. We stained sections of various organs with CD11c or MHC class II specific monoclonal antibodies. Dendritic cells in the kidney, heart, and intestine were found to be negative for CD11c expression. In the heart, most class II positive cells with a dendritic morphology (presumably dendritic cells) are located in the pericardium (fig 1A), whereas few cells were detected in the myocardium (not shown). Dendritic cells in both sites decreased in numbers after the injection of $E$ coli (fig 1B and data not shown). In the intestine, class II positive cells were detected in the connective tissue (lamina propria) of the villi (fig 1C). The injection of live bacteria resulted in the loss of most MHC class II positive cells (fig 1D). As shown in fig $1 \mathrm{E}, \mathrm{MHC}$ class II positive cells with a typical dendritic morphology could be found in the renal cortex around the glomeruli in the kidney of PBS treated mice. Intravenous inoculation of $E$ coli led to a reduction in the number of $\mathrm{MHC}$ class II positive cells (fig $1 \mathrm{~F}$ ).

INJECTION OF E COLI INDUCES PHENOTYPIC AND MORPHOLOGICAL CHANGES IN LUNG DENDRITIC CELLS AND THEIR MOVEMENT TO BLOOD VESSELS By contrast, the numbers of CD11c positive cells in lung remained unchanged after the inoculation of live $E$ coli (compare fig $1 \mathrm{G}$ and $1 \mathrm{H})$. Staining of lung sections with haemaluneosin clearly shows constriction of the alveoli (fig 2A and $\mathrm{B}$ ) and infiltration of the lung parenchyma by neutrophils (fig $2 \mathrm{D}$ and $\mathrm{E}$ ), starting one hour after the inoculation of live $E$ coli. In addition, immunostaining of sections revealed CD11c positive cells with a globular shape within the alveoli (fig 3A). These cells did not express MHC class II molecules (fig $3 \mathrm{~A}$ ) and could be alveolar macrophages or dendritic cells at a very immature stage (see below). Surprisingly, some of these CD11c positive cells (approximately 20-25\%) increased in size, acquired a dendritic morphology, and upregulated the expression of I-E molecules (fig 3B-E) as early as one hour after the injection of live bacteria. Later on (one to six hours after treatment), these dendritic like, CD11c positive, MHC class II positive cells seem to migrate to the blood vessels (fig 3C and D).

\section{Discussion}

Our report describes a new fixation and embedding technique, called Immunohistowax processing, that permits immunostaining of a large variety of antigens and preserves the morphology of all tissues tested. To achieve minimal denaturation of proteins during dehydration and embedding, the protein structures were stabilised by pretreatment with an aldehyde free zinc fixative before dehydration with ethanol or acetone. Tissue specimens were then embedded in an inert wax at $37^{\circ} \mathrm{C}$. This processing allowed antigen immunodetection and morphological analysis of thin sections (3-5 $\mu \mathrm{m})$.

The Immunohistowax processing technique allowed us to detect a trace population of APCs - cells of the dendritic family - in peripheral organs using phenotypic and morphological criteria.

It is generally believed that dendritic cells play the role of sentinels in the periphery, and upon the encounter of an appropriate signal (signal of danger?) are redistributed to $\mathrm{T}$ cell areas, where they probably prime $\mathrm{T}$ cells. ${ }^{26}$ The major role of dendritic cells in inducing primary immune responses correlates with some specialisation of function over time and space. In non-lymphoid tissues, dendritic cells are present in an immature state: well equipped to capture and process antigens but unable to sensitise $T$ cells optimally. In secondary lymphoid organs, dendritic cells are mature; that is, they poorly capture and process proteins but have the capacity to prime naive $T$ cells. The data presented here indicate that the inoculation of live bacteria induces the disappearance of most dendritic cells from the heart, kidney, and intestine. Their loss could be attributed to migration from these organs or death by apoptosis. We and others have shown previously that the injection of lipopolysaccharide or toxoplasma extracts provoked the migration of splenic dendritic cells from the marginal zone between the red and white pulp to the areas where $\mathrm{T}$ cells are located..$^{27}{ }^{28}$ These observations, together with those of Roake et $a l,{ }^{29}$ suggest that dendritic cells that have encountered bacteria might migrate to $\mathrm{T}$ cell zones in lymph nodes. Experiments are under way to test whether new migrant cells, bearing microbial antigens, can be detected in draining lymph nodes.

In the pulmonary alveoli, some CD11c positive cells acquire a dendritic morphology, upregulate the expression of MHC class II molecules, and migrate into proximal capillaries. These observations are reminiscent of a report by Randolph et $a l^{30}$ showing that monocytes differentiate into dendritic cells in vitro, after migration across the endothelium in the subluminal to lumenal direction, a phenomenon that is potentiated by an additional stimulus, such as lipopolysaccharide of zymosan particles. It is therefore tempting to speculate that, in the lung, MHC class II negative, CD11c positive monocytes are induced to differentiate into dendritic cells through crossendothelial migration and exposure to microorganisms. Additional work will be required to test this hypothesis.

In conclusion, Immunohistowax processing seems to allow optimal conservation of morphology and immunoreactivity. Indeed, almost all antigens tested were detected in Immunohistowax processed sections, including antigens that were not stained in paraffin wax embedded sections or cryosections. Of note, this method only requires standard equipment and does not rely on the antigen retrieval technique. We believe that Immunohistowax 
processing will be useful to identify in situ the cell populations that secrete various cytokines and to define more accurately the spatial and temporal organisation of the immune response.

We thank Drs Ralph Steinman (Rockefeller Institute, New York, USA), Gerry Klaus (National Institute for Medical Research, London, UK), Hervé Bazin (Université Catholique de Louvain, Bruxelles, Belgium), and John Shields (Cantab Pharmaceuticals, Cambridge, UK) for providing useful reagents; G Dewasme, $M$ Swaenepoel, $F$ Tielemans, and $\mathrm{P}$ Veirman fo technical assistance; and D Nolan for editorial assistance. The laboratory of animal physiology was supported by grants of the Fonds National de la Recherche Scientifique (FNRS)/Télévie, the Fonds de la Recherche Fondamentale Collective, the European Commission (CEC TMR Network Contract FMRXCT96-0053), and the Belgian Programme on Interuniversity Poles of Attraction initiated by the Belgian State, Prime Minister's Office, Science Policy Programming. TDS, CDT, RM-L, and $M M$ are supported by the FNRS

1 Steinman RM, Pack M, Inaba K. Dendritic cells in the T-cell areas of lymphoid organs. Immunol Rev 1997;156:25-37.

2 Zinkernagel RM, Ehl S, Aichele P, et al. Antigen localization regulates immune responses in a dose- and time-dependent fashion: a geographical view of immune reactivity. Immunol Rev 1997;156:199-209.

3 Ingulli E, Mondino A, Khoruts A, et al. In vivo detection of dendritic cell antigen presentation to $\mathrm{CD}^{+} \mathrm{T}$ cells. $\mathcal{F}$ Exp

4 Pudney J, Anderson D. Effects of fixation and paraffin embedding on the immunohistological detection of cellassociated HIV-1 by different monoclonal antibodies. $\mathcal{F}$ Histochem Cytochem 1995;41:857-62.

5 van Stokkum IHM, Linsdell H, Hadden JM, et al. Temperature-induced changes in protein structures studied by Fourier transform infrared spectroscopy and global analysis. Biochemistry 1995;34:10508-18.

6 Narhi LO, Philo JS, Li T, et al. Induction of $\alpha$-helix in the $\beta$-sheet protein tumor necrosis factor- $\alpha$ : thermal- and trifluoroethanol-induced denaturation at neutral $\mathrm{pH}$. Biochemistry 1996;35:11447-53.

7 Thomas PD, Dill KA. Local and nonlocal interactions in globular proteins and mechanisms of alcohol denaturation. Protein Sci 1993;2:2050-65.

8 Regan L, Clarke ND. A tetrahedral Zn(II)-binding site introduced into a designed protein. Biochemistry 1990;29. $10878-83$.

9 Kuroki R, Taniyama Y, Seko C, et al. Design and creation of a $\mathrm{Ca}^{2+}$ binding site in human lysozyme to enhance structural stability. Proc Natl Acad Sci U S A 1989;86:69037 .

10 Tainer JA, Roberts VA, Getzoff ED. Metal-binding site in proteins. Curr Opin Biotechnol 1991;2:582-91.

11 Tainer JA, Roberts VA, Getzoff ED. Protein metal-binding sites. Curr Opin Biotechnol 1992;3:378-87.

12 Christianson DW. Structural biology of zinc. Adv Protein Chem 1991;42:280-355.

13 Arnold FH, Zhang J-H. Metal-mediated protein stabilization. Trends Biotechnol 1994;12:189-92.
14 Coulie PG, Uyttenhove C, Wauters P, et al. Identification of a murine monoclonal antibody specific for an allotypic determinan 1703 .

15 Peterman GM, Spencer C, Sperling AI, et al. Role of gamma delta $\mathrm{T}$ cells in murine collagen-induced arthritis. f Immunol 1993;151:6546-58.

6 Payne J, Huber BT, Cannon NA, et al. Two monoclonal rat antibodies with specificity for the beta-chain variable region V beta 6 of the murine T-cell receptor. Proc Natl Acad Sci U S A 1998;85:7695-8.

17 Lefebvre M, Voncenzotto C, Digneffe C, et al. Rat monoclonal antibodies against murine immunoglobulins. In: Bazin H, ed. Rat hybridomas and rat monoclonal antibodies. Boca Raton, Florida, USA: CRC Press Inc, 1988:

Metlay JP, Witmer-Pack MD, Agger R, et al. The distinct leukocyte integrins of mouse spleen dendritic cells as idenleukocyte integrins of mouse spleen dendritic cells as iden-
tified with new hamster monoclonal antibodies. 7 Exp Med 1990;171:1753-71.

19 Hasbold J, Johnson-Léger C, Atkins CJ, et al. Properties of mouse CD40: cellular distribution of CD40 and B cell activation by monoclonal anti-mouse CD40 antibodies. Eur F Immunol 1994;24:1835-42.

20 Inaba K, Steinman RM, Witmer-Pack M, et al. Identification of proliferating dendritic cell precursors in mouse blood. F Exp Med 1992;175:1157-67.

21 Agger R, Witmer-Pack M, Romani N, et al. Two populations of splenic dendritic cells detected with M342, a new monoclonal to an intracellular antigen on interdigitating dendritic cells and some B lymphocytes. F Leukoc Biol 1992;52:34-42.

22 Kraal G, Breel M, Jnase M, et al. Langerhans cells, veiled cells, and interdigitating cells in the mouse recognized by a monoclonal antibody. F Exp Med 1986;163:981-97.

23 Hathcock KS, Lazlo G, Dickler HB, et al. Identification of an alternative CTLA4-ligand costimulatory for T cell activation. Science 1993;262:905-7.

24 Paineau J, Priestley C, Fabre J, et al. Effect of recombinant interferon gamma and interleukin-2 and of a monoclonal antibody against interferon gamma on the rat immune response against heart allografts. F Heart Lung Transplant 1991;10:424-30

25 De Smedt T, Pajak B, Klaus GGB, et al. Antigen-specific T lymphocytes regulate lipopolysaccharide-induced apoptosis of dendritic cells in vivo. F Immunol 1998;161:4476-9.

26 Banchereau J, Steinman RM. Dendritic cells and the control of immunity. Nature 1998;392:245-52.

27 De Smedt T, Pajak B, Muraille E, et al. Regulation of dendritic cell numbers and maturation by lipopolysaccharide in vivo. 7 Exp Med 1996;184:1413-24.

28 Reis e Sousa C, Hieny S, Scharton-Kersten T, et al. In vivo microbial stimulation induces rapid CD40 ligandmicrobial stimulation induces rapid CD40 ligandindependent production of interleukin 2 by dendritic cells and their redistrib

29 Roake JA, Rao AS, Morris PJ, et al. Dendritic cell loss from nonlymphoid tissues after systemic administration of ipopolysaccharide, tumor necrosis factor, and interleukin 1. F Exp Med 1995;181:2237-47.

30 Randolph GJ, Beaulieu S, Lebecque S, et al. Differentiation of monocytes into dendritic cells in a model of transendothelial trafficking. Science 1998;282:480-3. 